In search of the elusive Chinese urban middle class: An exploratory analysis

\title{
Céline BONNEFOND
}

\&

Matthieu CLEMENT

\&

François COMBARNOUS

GREThA, CNRS, UMR 5113

Université de Bordeaux

Cahiers du GREThA

$\mathrm{n}^{\circ}$ 2013-19

September

\author{
GRETHA UMR CNRS 5113 \\ Université Montesquieu Bordeaux IV \\ Avenue Léon Duguit - 33608 PESSAC - FRANCE \\ Tel : +33 (0)5.56.84.25.75 - Fax : +33 (0)5.56.84.86.47 - www.gretha.fr
}


A la recherche de l'insaisissable classe moyenne urbaine chinoise : une analyse exploratoire

\title{
Résumé
}

L'objectif de cet article est d'identifier et de caractériser la classe moyenne urbaine chinoise. Nous proposons d'améliorer la description de cette classe moyenne en combinant une approche économique (basée sur le revenu) et une approche sociologique (basée sur l'emploi et l'éducation). Les investigations mises en œuvre sont basées sur les données de l'enquête China Health and Nutrition Survey pour l'année 2009. Dans un premier temps, la classe moyenne est définie comme l'ensemble des ménages dont le revenu annuel par tête est compris entre 10000 yuans et le $95^{\text {ème }}$ percentile de la distribution du revenu. Sur cette base, environ $50 \%$ des ménages urbains sont considérés comme appartenant à la classe moyenne urbaine chinoise. Dans un second temps, nous utilisons les informations sur l'emploi et l'éducation pour caractériser l'hétérogénéité de cette catégorie sociale intermédiaire. En utilisant une méthode de classification, nous identifions quatre groupes au sein de la classe moyenne chinoise : (i) une classe moyenne de retraités et d'inactifs; (ii) I'" ancienne " classe moyenne composée de travailleurs indépendants; (iii) la classe moyenne inférieure composée d'ouvriers qualifiés et non qualifiés et (iv) la "nouvelle" classe moyenne composée de salariés hautement qualifiés du secteur public. Nous montrons également que ces différents groups présentent de réelles spécificités concernant le logement ou les biens d'équipement.

Mots-clés : stratification sociale, distribution du revenu, classe moyenne, Chine, méthodes de classification

In search of the elusive Chinese urban middle class: An exploratory analysis

\begin{abstract}
This paper aims to identify and characterize the Chinese urban middle class. We propose to improve the description of the middle class using an innovative approach combining an economic approach (based on income) and a sociological approach (based on education and occupation). The empirical investigations conducted as part of this research are based on the China Health and Nutrition Survey (2009). First, we define the middle income class as households with an annual per capita income between 10,000 yuan and the $95^{\text {th }}$ percentile. On this basis, approximately fifty percent of urban households may be said to belong to the middle class. Second, we use information on employment and education to characterize the heterogeneity of the middle income class. Using clustering methods, we identify four groups: (i) the elderly and the inactive middle class, mainly composed of pensioners; (ii) the old middle class, composed of self-employed workers; (iii) the marginal middle class, composed of skilled and unskilled workers; and (iv) the new middle class, composed of highly educated wage earners in the public sector. We show that the different groups have distinctive features based on variables such as housing and household appliances and equipment.
\end{abstract}

Keywords: social stratification, income distribution, middle class, urban China, clustering methods.

JEL: O53, P25, P36, Z13

Reference to this paper: BONNEFOND Céline, CLEMENT Matthieu, COMBARNOUS François (2013) In search of the elusive Chinese urban middle class: An exploratory analysis, Cahiers $d u$ GREThA, $n^{\circ} 2013-$ 19.

http://ideas.repec.org/p/grt/wpegrt/2013-19.html. 


\section{Introduction}

One of the effects of increasing wealth and the drastic reduction in poverty rates in China since the beginning of economic reforms is the emergence of a new social group known as the "new rich". However, this new socio-economic category has many of the characteristics of a new middle class. As noted by Tomba (2004), the emergence of a new middle class has been one of the most important determinants of social change over the past decade. In an influential study of the global middle class, Ravallion (2010) shows that the share of the Chinese middle class (i.e. people with an income of $\$ 2$ to $\$ 13$ per day) in total population increased from $15.3 \%$ in 1990 to $61.8 \%$ in 2005. Many other studies have provided evidence of the widening income distribution and the growth of the middle class (Wilson and Dragusanu, 2008; ADB, 2010; Yuan et al., 2011; Bonnefond and Clément, 2012).

The rise of the Chinese middle class is explained first by China's economic boom since the beginning of the reforms. The increasing openness and liberalization of the Chinese economy has resulted in a significant increase in mean per capita income. However, the expansion of the Chinese middle class is also related to socio-economic factors such as urbanization and urban housing reforms, the development of higher education, property rights reforms, and the westernization of lifestyles under the influence of globalization and the mass media, among other things (Chunling, 2010; Li, 2010). Following Li (2010), we may argue that two categories of actors have contributed to the rise of the Chinese middle class. The first is the business community, which has played a crucial role in promoting the idea of the middle class since the rise of the middle class is associated with the expansion of the domestic market and is a driving force for private consumption. The second actor is the Chinese state, a key factor in the rise of the middle class (Tomba, 2004; Li, 2010; Elfick, 2011). While the Maoist regime led to the near disappearance of social classes, the adoption of a strategy of inclusive growth from the 2000s has come to be seen as a major turning point in China's development path. In 2002, the sixteenth national party congress called for an increase in the size of the middle income group (zhongdeng shouru qunti) and the development of an affluent society. These objectives were institutionalized in the $11^{\text {th }}$ Five-Year Plan (2006-2010), which emphasized the promotion of a 'harmonious society', and the $12^{\text {th }}$ Five-Year Plan (2011-2015), which aims to improve livelihoods and to promote the transition to a "happier society". The shift to a strategy of inclusive growth has led the Chinese authorities to re-appropriate the Confucian concept of xiaokang, which refers to the idea of a moderately well-off society or a middle class society (Hanlong, 2010).

Why is the analysis of the Chinese middle class an important issue for economists? In Western countries, the emergence of the middle class contributed significantly to the acceleration of economic development at the end of the nineteenth century (Landes, 1998) and to the perpetuation of high growth rates during the post-World War II period. The significant expansion of the middle income classes in emerging countries (mainly in Asia, and in China in particular) may ensure the sustainability of development, just as it did in the West. Broadly speaking, the emerging middle class may be seen as a catalyst, i.e. as a class driving socio-economic and political change. The middle class is assumed to be a catalyst through two main channels. First, the emergence of a large middle class is considered to be a driver of consumption (Banerjee and Duflo, 2008). Research suggests that the expansion of the middle class and the associated reduction in poverty tend to result in increased household expenditure, while also resulting in a change in consumption patterns. Compared to poor people, middle class members are assumed to spend a lower percentage of their income on necessity goods and to spend more on discretionary and luxury goods and household appliances and equipment. Therefore, the emergence of a middle class is associated with a higher demand for highquality goods (Murphy et al., 1989; Matsuyama, 2002; Foellmi and Zweimuller, 2006). Second, there is evidence to suggest that the emergence of a large middle class may help to strengthen social cohesion and political stability and even promote democratization (Lipset, 1959; Muller, 1997; Easterly, 2001; Loayza et al., 2012). The underlying idea is that societies with a growing middle class 
are less polarized and are therefore more inclined to implement policies in favor of economic and social development. The middle class acts as a buffer zone between the poor and the rich (Jing, 2010) and, as explained by Easterly (2001), the establishment of a "middle class consensus" is a driving force in promoting good institutions, good policies and democratic governance.

The Chinese middle class is an ambivalent entity since it is at the vanguard of consumption but at the rearguard of politics (Xiaohong and Chen, 2010). In other words, the public image of the middle class is closely related to the first channel and is associated with the westernization of lifestyles. What is this public image? Typical members of China's middle class are urban, buy modern cars, own modern flats or houses, purchase high-technology products such as flat screen TVs and mobile phones, travel around the world, and are able to obtain credit. These developments suggest that the Chinese middle class is the driving force of a real "consumer revolution" (Elfick, 2011). These distinctive features are primarily relayed by the mass media, but are also found in reports published by institutions providing a picture of Asian or Chinese middle classes (McKinsey Global Institute, 2006; ADB, 2010; Deutsche Bank, 2009; Goldman Sachs ${ }^{1}$ ). The literature devoted to the analysis of the Chinese middle class is mainly sociological and managerial, and economists are currently lagging behind on these issues, probably because the main focus of their work over the past two decades has been the analysis of income inequality.

The middle class is found in all major Chinese cities. However, there is no consensus on the method of identifying (i.e. characterizing) the middle class, for two main reasons. First, the concept of middle class is a fuzzy, controversial and cross-disciplinary concept. As noted by Pressman (2007) and Chunling (2010), there are many approaches to the definition and identification of the middle class. We can distinguish four disciplinary approaches: (i) an economic approach (based on income), (ii) a sociological approach (based on occupation and education), (iii) a subjective approach (based on class consciousness), and (iv) a managerial approach (based on consumption habits). In each approach, there is a wide range of definitions and methods of identification. Second, the Chinese middle class is highly heterogeneous. As argued by Li (2010: 4), "China's emerging middle class is, of course, a complex mosaic of groups and individuals" that differ on many social, economic and demographic characteristics.

This paper has two main objectives. First, using factor analysis and clustering methods, we propose to improve the identification and characterization of China's middle class using an original approach combining an economic approach (income) and a sociological approach (education and occupation). Second, based on a wide range of socio-economic variables, a statistical analysis is performed to demonstrate the heterogeneity of the Chinese middle class. The paper focuses on urban China and uses household-level data from the China Health and Nutrition Survey. The article is structured as follows. Section 2 reviews the literature on the identification and definition of the middle class and describes the statistical methodology. Section 3 describes the data, while section 4 presents and discusses the results.

\section{Identifying and characterizing the middle class: an innovative statistical approach}

\subsection{Identifying the middle income class}

Since the 1980s, an extensive economic literature has developed on the decline of the middle class in industrialized countries (Blackburn and Bloom, 1985; Horrigan and Haugen, 1988; Pressman,

\footnotetext{
${ }^{1}$ See Wilson and Dragusanu (2008).
} 
2007). These studies, but also more recent studies devoted to the emergence of the middle class in developing countries, use an income-based definition of the middle class where people who fall within a specific income range (or other monetary indicator) are considered to belong to the middle income class. In this view, the important question is the definition of the lower and upper boundaries of the income range. There is no consensus in the empirical literature, and the definitions and descriptions of the middle class that result from different ranges are often contradictory. However, four ways of defining the middle income class can be identified in the literature.

The first approach is relative and defines the middle class as the population located in the middle of the distribution of a monetary indicator, such as income, consumption or wage. In this approach, one of the most commonly used criteria identifies the middle class as people earning between $75 \%$ and $125 \%$ of the median income (Thurow, 1987; Birdsall et al., 2000; Pressman, 2007). ${ }^{2}$ Other relative criteria are based on quintiles. For example, Easterly (2001) considers that the middle class includes households belonging to the second, third and fourth expenditure quintiles, while Alesina and Perotti (1996) and Castellani and Parent (2011) consider the third and fourth income quintiles. Second, the absolute approach is often used in current research since the boundaries (PPP adjusted) are time-constant and common to all countries, thus allowing for international comparisons. However, in the same way as for the relative approach, there is no consensus on how to determine an appropriate income range. According to Milanovic and Yitzhaki (2002), the middle class is composed of households with a daily income ranging between the mean per capita income of Brazil and Italy, i.e. roughly between $\$ 10$ and \$20 in PPP 2005. Kharas (2010) considers a larger interval, from $\$ 10$ to $\$ 100$. Recent studies have viewed people belonging to the middle class as poorer than previous absolute criteria by referring to the $\$ 2$ international poverty line (PPP 2005). ${ }^{3}$ The underlying assumption is that the middle class begins where poverty ends. The upper limit is more arbitrary. Ravallion (2010) uses the US poverty line, i.e. $\$ 13$ a day (PPP 2005). The upper limit is sometimes set at $\$ 10$ (Banerjee and Duflo, 2008) or \$20 (ADB, 2010; Castellani and Parent, 2011). A third category of empirical studies uses a mixed approach combining an absolute lower boundary and a relative upper boundary (Birdsall, 2010; Sosa Escudero and Petralia, 2010). In particular, Birdsall (2010) proposes a lower limit set at $\$ 10$ a day (PPP 2005) that is high enough (compared to the $\$ 2$ threshold) to ensure people whose income is higher have reached a certain level of economic security. The upper boundary is fixed at the $95^{\text {th }}$ income percentile. According to Birdsall (2010), this relative and therefore country-specific limit excludes "that portion of the population within a country whose income is most likely to be from inherited wealth, or based on prior or current economic rents (...) and thus less associated with productive and primarily labor activity than for the non rich" (Birdsall, 2010: 7). The fourth approach involves adopting a poverty line based definition of the middle class. The underlying idea is to construct an income range based on the national poverty line. For Burkhauser et al. (1996), the middle class includes households with an income between two and five times the country-specific poverty line. Peichl et al. (2010) adopt a relative approach and set the middle class between the poverty threshold defined as $60 \%$ of the median income and a wealth threshold equal to $200 \%$ of the median income (i.e. $333 \%$ of the poverty threshold).

In China, the identification of the middle income group is often based on an absolute approach, although there is no consensus on the lower and upper boundaries. Wilson and Dragusanu (2008), for Goldman Sachs, define a lower limit of $\$ 6,000$ and an upper limit of $\$ 60,000$ (i.e. $\$ 16$ and $\$ 82$ a day respectively), whereas ADB (2010) uses an income range of $\$ 2$ to $\$ 20$ a day. Because the two criteria only overlap for the $\$ 16-\$ 20$ bracket, they give a different picture of the Chinese middle class. It is worth noting that the ADB's estimation has been widely criticized for overestimating the size of China's middle class. ${ }^{4}$ The lowest limit of \$2 (PPP adjusted) adopted by ADB (2010), but also by

\footnotetext{
${ }^{2}$ Other studies use wider ranges around the median income. See Blackburn and Bloom (1985) and Castellani and Parent (2011).

${ }^{3}$ The international poverty line is defined as the median national poverty line for 70 developing countries (Ravallion, 2010).

${ }^{4}$ See the note by Rose Scobie in the Economic Observer, http://www.eeo.com.cn/ens/observations/2010/09/15/180857.shtml
} 
Ravallion (2010), is highly debatable since it suggests that it is enough to be non-poor (i.e. to earn more than $\$ 2$ a day) to be considered a member of the middle class. As ADB (2010) acknowledges, "the majority of the Asian middle class still falls in the $\$ 2-\$ 4$ range, leaving them highly vulnerable to slipping back into poverty due to economic shocks" (ADB, 2010: 3). This idea was already present in Horrigan and Haugen (1988: 5), who argue that we have "to ensure that the lower endpoint of the middle class represents an income significantly above the poverty level". Empirical studies on the middle class devoted specifically to China (and not devoted to international comparisons) adopt higher income ranges than those used by ADB (2010). However, upper and lower boundaries are often applied to household income rather than per capita household income, which can cloud comparisons. For instance, McKinsey Global Institute (2006) defines the Chinese urban middle class as households earning between 25,000 and 100,000 yuan a year (between $\$ 13,500$ and $\$ 53,900$, PPP adjusted), while the National Bureau of Statistics uses a range of 60,000 to 500,000 yuan for a threemember household. When we consider a per capita basis, Wang and Davis (2010) suggest that 10,000 yuan is a minimum threshold marking entry into a lifestyle corresponding to the middle class in urban China.

How should we interpret the wide range of criteria? Although the relative approach seems intuitive and produces country-specific boundaries, it is not well-suited to the analysis of trends and changes over time since the share of the middle class is not or weakly sensitive to changes in income distribution. As we discussed above, the absolute approach is useful for international comparisons but seems too arbitrary for a country-specific analysis. The poverty-line based approach aims to reduce arbitrariness in the definition of boundaries. However, it raises issues in the Chinese context since the official poverty line is very low, which could result in a biased identification of the middle class. ${ }^{5}$ These objections suggest that we need to adopt the mixed approach combining an absolute lower boundary and a relative upper boundary. Following Wang and Davis (2010), the lower boundary is set at 10,000 yuan. This minimum threshold enables us to focus on households that escape poverty on a permanent basis and have reached a reasonable level of socio-economic security. In line with Birdsall (2010), the relative upper limit is the $95^{\text {th }}$ percentile of the income distribution. The urban Chinese middle class is thus defined as all households with an annual per capita income between 10,000 yuan and the $95^{\text {th }}$ income percentile.

\subsection{Multidimensional characterization of the middle class}

Although the most commonly used method for identifying the middle class in the economic literature involves a strictly monetary (financial) approach, we propose to improve and expand the purely income-based approach by considering occupation and education, the chief focus of the sociological literature on class structure.

In a study of the Chinese middle class, Wang and Davis (2010) argue that occupation determines class homogeneity. According to Jing (2010), the changing class structure of Chinese society has followed a similar pattern to industrialized countries, particularly in terms of occupational structure. However, the sociological literature focusing on occupation and education is diverse. Goodman (2008) takes a narrow view of the Chinese middle class, focusing solely on ownership of the means of production and entrepreneurship from a Marxist perspective (here, classes are assumed to be defined by their relationship to the means of production). This definition is often referred to as the old middle class and can be associated with the petty bourgeoisie. Other studies that recognize the specificity of the Chinese middle class use a broader spectrum of occupations and include high-wage earners in the middle class. One of the most influential studies of social

\footnotetext{
${ }^{5}$ In 2009, the official Chinese poverty line was set at 1,196 yuan a year. On this basis, only $8 \%$ of the population was considered to be poor in 2009 (CIA World Factbook). As a comparison, according to international standards (World Bank, World Development Indicators), in 2008, $13.06 \%$ of the Chinese population were living on less than $1.25 \$$ a day (in 2005 PPP) and $29.79 \%$ on less than $2 \$$.
} 
stratification in China was by sociologists from the Chinese Academy of Social Sciences (Lu, 2002; 2012). Using occupation as the main criterion, Chinese society is divided into ten occupation-based categories: top executives and government officials, managers, private entrepreneurs, professional and technical workers, clerical workers, self-employed workers, sales and service workers, manual workers, agricultural workers and the unemployed. From these ten categories, five socio-economic groups are defined: the upper, the upper middle, the middle, the lower middle and the lower groups. It is worth noting that each member of a specific occupation-based stratum can potentially belong to several socio-economic groups. For instance, a manager may belong either to the upper group or to the upper middle group. Following the seminal work of Mills (1951) on the American class structure, Chunling (2010) also proposes an innovative approach to China's class structure. She considers four groups in the Chinese middle class: (i) the capitalist class, composed of private entrepreneurs; ${ }^{6}$ (ii) the old middle class, composed of small employers, small business owners and self-employed workers; (iii) the new middle class, composed of wage earners such as officials, professionals and managers in the public sector and professionals and managers in the private sector; and (iv) the marginal middle class, composed of low-wage white collar workers and other workers. Li (2010) distinguishes three components in the Chinese middle class: an economic component (private entrepreneurs, small urban businesses, rural industrialists, etc.), a political component (government officials, public sector managers, office clerks, etc.) and a cultural and educational component (academics and educators, intellectuals, media personalities, etc.).

How can we reconcile the economic and sociological approaches to the middle class? We propose to use a multidimensional approach combining an income-based definition of the middle class and an occupation/education-based definition. In this view, there are two possible methodologies.

The first method involves constructing a multidimensional index of social status and defining upper and lower boundaries to apply to the composite index. In the sociological field, there are a number of well-known indices. The first is Warner's index of status characteristics (Warner et al., 1949) based on four dimensions (occupation, source of income, house type and dwelling). The Hollingshead two-factor index of social position (ISP), probably one of the most influential indices, includes two dimensions (occupation and education; Hollingshead and Redlich, 1958). ${ }^{7}$ We may also refer to the Computerized Status Index (CSI) developed by Coleman (1983), which takes into account education (of an individual and his/her spouse), occupational prestige, area of residence and income. These indices are calculated as the weighted sum of the scores that individuals attain in each selected dimension. Social classes are identified by applying lower and upper boundaries. Composite indices recognize the multidimensionality of social status and provide a more detailed description of social classes than a single variable. However, they raise two issues. First, the weighting of dimensions is relatively subjective. As an illustration, the Hollingshead ISP assigns a weight of 7 to occupation and 4 to education, while the CSI assigns a weight of 2 to occupational prestige and a weight of 1 to the other dimensions. In other words, there is no objective criterion for defining the relative importance of different dimensions. Second, the identification of social classes relies on ad hoc boundaries. For instance, the CSI is a global score ranging from 4 to 53. Coleman (1983) arbitrarily defines the middle class as including all individuals with a score ranging from 24 to 36 . The same comment applies to Warner's and Hollingshead's indices.

Given the limitations of composite indices of social status, we prefer to use a more innovative approach involving two stages. In the first stage, we use the above-mentioned income-based definition to describe the Chinese urban middle class, thus prioritizing a financial criterion. In the

\footnotetext{
${ }^{6}$ The capitalist class is generally included in the upper class and is not considered to be a part of the middle class. However, Chunling (2010) argues that because it is a new group in China, the upper class symbolizes the expansion of the middle class.

${ }^{7}$ Hollingshead (1976) proposed the ISP index, which includes four factors (occupation, education, sex and marital status).
} 
second stage, we use data on occupation and education to analyze the structure of the previously identified middle income class. Although income is closely correlated with occupation and education, these characteristics help to improve the identification and characterization of the middle class and to demonstrate its heterogeneity. To implement the second stage, we implement a classification procedure to establish homogeneous and meaningful clusters of households in terms of their multidimensional "middle class status".

\section{Data}

The data used in this study come from the China Health and Nutrition Survey (CHNS), a collaborative project between the Carolina Population Center (University of North Carolina) and the Chinese Center for Disease Control and Prevention. The CHNS involves a multi-wave longitudinal study providing detailed information on income, labor market, education, health, nutrition and migration (among other things). The first survey was conducted in 1989. Seven other waves (1991, 1993, 1997, 2000, 2004, 2006 and 2009) are now available. The survey covers nine provinces, including coastal provinces (Shandong and Jiangsu), northeastern provinces (Heilongjiang and Liaoning) and inland provinces (Henan, Hubei, Hunan, Guangxi and Guizhou). Although the survey is not nationally representative, provinces were selected to provide a diverse picture of Chinese provinces in terms of geography, economic development and health and nutritional outcomes. The sample was selected by multistage random cluster sampling ${ }^{8}$ and covered approximately 4,400 households in 2009.

This study focuses primarily on the 2009 wave. The other waves are used to demonstrate the extent to which the middle class has changed. We only consider the sub-sample of urban households composed of 1,320 households after checking for missing values. The sample does not include major Chinese cities such as Beijing, Shanghai, Guangzhou, Shenzhen, Tianjin, Chongqing or Hong Kong. However, other major cities are covered since for each province the provincial capital and a lowerincome city are included. It is worth noting that the urbanization profile of the nine provinces is relatively heterogeneous, including both highly urbanized provinces (Liaoning and Jiangsu) and less urbanized provinces (Henan and Guizhou).

Although CHNS data are primarily designed for the analysis of health and nutrition issues, they also include basic information on income, occupation and education - i.e. the three dimensions used to identify the middle class. The first variable is household income expressed in per capita annual income and composed of wages, retirement income, business income, subsidies, agricultural income and other income (private transfers and rent). At an individual level, CHNS data provide detailed information on employment and education. Because our analysis is at a household level, we use information on occupation and education for household heads. Four classification variables are considered: primary occupation (professional or technical worker, administrator or executive, office staff, skilled or unskilled worker, service worker, retired, inactive, etc.), employment position (selfemployed, salaried employee, etc.), the type of work unit (government department, state service, state-owned, collective or private enterprise, etc.) and level of education (highest level of education completed).

Our analysis also requires additional variables to describe the profile of China's middle class. These variables relate to household head characteristics (age and marital status), household characteristics (size, activity ratio, province of residence) and housing (homeowner or tenant, surface, number of rooms). CHNS data include rich information on household appliances and equipment. We use data on computer and car ownership. We also created a composite index of

\footnotetext{
${ }^{8}$ For a description of the sampling scheme, see Popkin et al. (2009).
} 
household appliances and equipment that takes into account ten types of goods: color TV, washing machine, refrigerator, air conditioner, computer, camera, microwave oven, cell phone, VCD/DVD, and automobile. The household appliances and equipment index has the advantage of comparing household appliances and equipment with an ad hoc equipment standard, rather than simply adding up a wide range of household appliances and equipment. Instead of measuring an inevitably heterogeneous stock of household appliances and equipment, we consider the degree of over or under-equipment of households compared with a local standard. ${ }^{9}$ The index is computed by adding up, for each of the ten household appliances and equipment, $a+1$ score if the household is overequipped (for example, because the household has more than one television) and a -1 score if the household is under-equipped (for example, because the household does not have a refrigerator). The index is brought within the $[0 ; 1]$ interval using linear interpolation. The last characterization variable is the urbanization index developed by Jones-Smith and Popkin (2010) and included in CHNS data. ${ }^{10}$

\section{Results}

\subsection{The middle income class: identification, evolution and characterization}

Table 1 compares the middle class income boundaries derived from four different criteria and their implications for the size of the middle class. We consider one criterion for each of the four approaches identified above: an absolute criterion (between $\$ 2$ and $\$ 20)$, a relative criterion (75\%$125 \%$ of 2009 median income), a poverty line based criterion (between two and five times the national poverty line) and a mixed criterion (between 10,000 yuan and the $95^{\text {th }}$ percentile). The main finding is that the lower and upper limits of different criteria do not converge, resulting in significant differences in estimates of the size of China's urban middle class. The share of the middle income class ranges from $15.8 \%$ based on the poverty line based approach to approximately $80 \%$ based on the absolute approach. Both criteria give an inaccurate picture of China's income distribution. The absolute approach gives a wide income range (between 3,257 and 32,573 yuan). Although the figure of $80 \%$ of urban households belonging to the middle class is consistent with ADB estimates (ADB, 2010), ${ }^{11}$ the lower extremity of the income range is debatable. As explained above, considering households whose daily per capita income is between \$2 and \$4 is not satisfactory since these households are probably still vulnerable to poverty. The poverty line based approach defining the middle class as households with per capita income between two and five times the national poverty line gives an income range in the lower tail of the income distribution. It is worth noting that this criterion only intersects with the lower end of the income range associated with the absolute approach. In other words, the wealthiest households of the middle income group have a per capita income of $\$ 2$ to $\$ 4$ a day. This criterion is misleading since it clearly underestimates the size of the middle class and only identifies poor and vulnerable households as belonging to the middle class. The main problem with this approach lies in the underestimation of the Chinese poverty line, as noted above. The last two criteria seem more realistic despite producing different estimates of the size of the middle class. With the mixed approach, $50 \%$ of urban households are found to belong to the middle class, i.e. more than twice the size of the middle class identified using the relative approach ( $75 \%-125 \%$ of 2009 median income). One advantage of a mixed criterion compared to a relative criterion is its ability to adequately capture trends and changes over time.

\footnotetext{
${ }^{9}$ In our sample, "normal" equipment is refers to a household that owns a television, a refrigerator, a washing machine and one or two cell phones, but no VCD/DVD, camera, computer, microwave, air conditioner or car.

${ }^{10}$ Based on community-level data, this index is a composite measure synthesizing the information on twelve dimensions of urbanicity: population density, economic activity, traditional markets, modern markets, transportation infrastructure, sanitation, communications, housing, education, diversity (in education and income levels), health infrastructure and social services. For each component, a score ranging from 0 to 10 is calculated. The global index is the sum of the twelve component scores. A higher urbanization score indicates higher urbanicity. See Jones-Smith and Popkin (2010) for more details.

${ }^{11}$ Using the CHIP (Chinese Household Income Project) household survey for 2007 and the \$2-\$20 criterion, ADB's estimates show that the share of the urban middle class in total population is over $91 \%$ (ADB, 2010).
} 
Table 1: Comparison of different criteria for defining the middle income class (urban households, 2009).

\begin{tabular}{|c|c|c|c|c|c|c|}
\hline \multirow[t]{2}{*}{ Approach } & \multirow[t]{2}{*}{ Criterion } & \multicolumn{2}{|c|}{ Middle class income range ${ }^{1}$} & \multirow{2}{*}{$\begin{array}{l}\text { Middle } \\
\text { class }\end{array}$} & \multirow[t]{2}{*}{ Poor } & \multirow[t]{2}{*}{ Rich } \\
\hline & & $\begin{array}{l}\text { Annual per capita } \\
\text { yuan (2009 prices) }\end{array}$ & $\begin{array}{c}\text { Annual per capita } \\
\$(\text { PPP, } 2009 \text { prices) }\end{array}$ & & & \\
\hline Mixed & {$[10,000$ yuan; P95] } & {$[10,000 ; 36,285]$} & {$[2,487 ; 9,026]$} & $49.9 \%$ & $45.1 \%$ & $5 \%$ \\
\hline Absolute & [\$2 PPP; \$20 PPP] & {$[3,257 ; 32,573]$} & {$[810 ; 8,102]$} & $79.5 \%$ & $13.9 \%$ & $6.6 \%$ \\
\hline Relative & $\begin{array}{c}{[75 \%-125 \% \text { of }} \\
\text { median income] }\end{array}$ & {$[8473 ; 14122]$} & {$[2,107 ; 3,513]$} & $21.8 \%$ & $39.3 \%$ & $38.9 \%$ \\
\hline $\begin{array}{c}\text { Poverty line } \\
\text { based }\end{array}$ & $\begin{array}{l}\text { [Between } 2 \text { and } 5 \text { times } \\
\text { national poverty line] }{ }^{2}\end{array}$ & {$[2392 ; 5980]$} & {$[595 ; 1487]$} & $15.8 \%$ & $10.4 \%$ & $73.8 \%$ \\
\hline \multicolumn{7}{|c|}{$\begin{array}{l}\text { Notes: (1) The PPP conversion factor is } 4.462 \text { for the year 2009. It is calculated using the urban PPP conversion } \\
\text { rate for } 2005 \text { derived from PovcalNet data (World Bank) and consumer price indices stem from China Statistical } \\
\text { Yearbooks (National Bureau of Statistics of China). (2) The national official poverty line is set at 1,196 annual } \\
\text { yuan. }\end{array}$} \\
\hline
\end{tabular}

Figure 1 shows the changing size of the Chinese urban middle income class between 1989 and 2009 based on the four criteria described above. The poverty line based approach indicates that the size of the Chinese middle class decreased from over 60\% in 1989 to around $15 \%$ in 2009. This counter-intuitive trend confirms the limitations of the poverty line approach. Given the underestimation of the Chinese poverty line, this criterion is more an indication of the reduction in poverty that has occurred since the beginning of the reforms (Ravallion and Chen, 2007) than an indication of the expansion of middle and higher groups. The absolute approach gives a very different picture. With the $\$ 2-\$ 20$ criterion, the size of the Chinese middle class appears to have increased significantly over the study period. However, there were already $44.7 \%$ of people belonging to the middle class in 1989 , which seems unlikely given that respectively $60.2 \%$ and $84.6 \%$ of the Chinese population were living on less than $1.25 \$$ and $2 \$$ a day in 1990 (Ravallion and Chen, 2010). Once again, the relative and the mixed criteria seem more appropriate since they confirm that the middle class was almost non-existent until the mid 1990s. However, they highlight different expansion patterns in China's urban middle class. Based on the relative criterion, the middle class may be said to have emerged in the mid-1990s and to have grown rapidly until the mid-2000s. Since then, the share of the middle class has remained stable and even decreased slightly between 2006 and 2009. The relative approach tends to smooth out the temporal evolution of the middle class and is therefore not well-suited to demonstrating the extent of the recent increase in the size of the middle class. The mixed approach shows that the rise of China's urban middle class is a more recent phenomenon dating back to the early 2000s. Not surprisingly, the increase is more pronounced and uninterrupted and probably better reflects the growth of the middle class. 
Figure 1: Evolution of the size of the Chinese urban middle class between 1989 and 2009 regarding different identification criteria (urban households, 1989-2009).

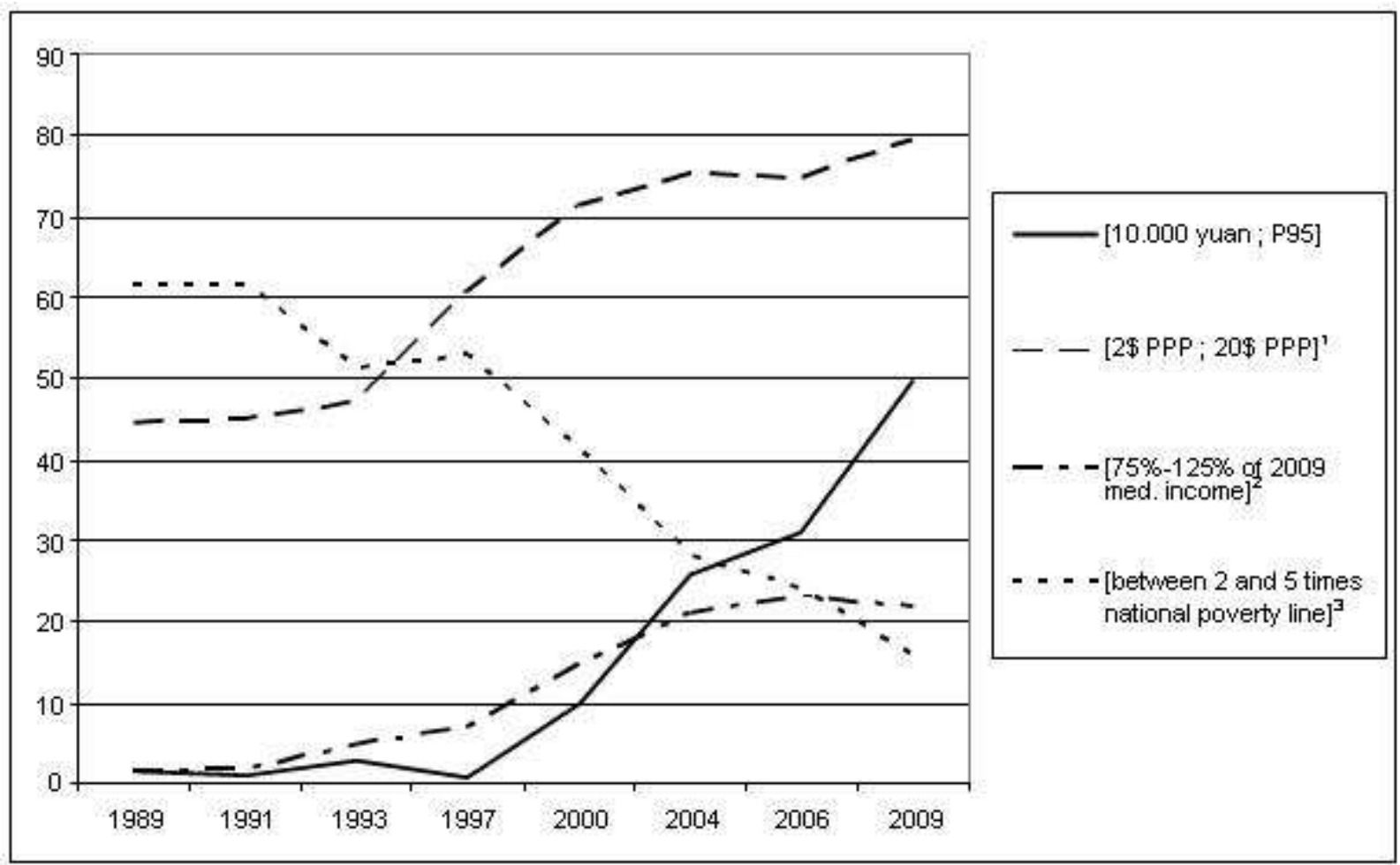

Source: CHNS (1989, 1991, 1993, 1997, 200, 2004, 2006, 2009)

PPP = purchasing power parity.

Notes: (1) The PPP conversion factor is 4.462 for the year 2009. It is calculated using the urban PPP conversion rate for 2005 derived from PovcalNet data (World Bank) and consumer price indices stem from China Statistical Yearbooks (National Bureau of Statistics of China). (2) For the relative approach, the boundaries are calculated from the 2009 median income and remain the same for the preceding years (adjusted for inflation). (3) The national official poverty line is set at 1,196 annual yuan (2009 prices).

In short, the comparison of the four approaches confirms that the choice of income boundaries is critical and may lead to a misidentification of the middle income group or an underestimation of its increase. Our findings indicate that the mixed criterion must be privileged in this respect.

Before analyzing the heterogeneity of the Chinese urban middle class, we propose to discuss its similarities with poor and rich households and its distinctive features. The distributions or means of classification and characterization variables for each of the three groups are reported in Table 2 . Not surprisingly, households belonging to middle and high income categories are headed by people with higher levels of education. In 2009, $17.9 \%$ of household heads in the middle class had completed a technical or vocational degree, while $18.2 \%$ had a master's degree or higher. Household heads with no education or primary education are significantly more numerous in the poor category. The Chinese middle class is clearly distinct from both the poor and the rich in terms of employment category, employment status and work unit. The findings indicate that the middle class is composed of a significantly higher proportion of households whose head belongs to the professional and technical worker category (15.7\%), the administrator and executive category (8.1\%), and the office staff category (5.6\%). It also includes a significant proportion of pensioners $(43.2 \%)$. Clearly, the diverse occupational profile of the Chinese urban middle class suggests that the middle income group is heterogeneous and validates the multidimensional approach. Another distinctive feature of China's urban middle class is its over-representation in the salaried employee category (41.4\%), particularly among people working in government departments or state services $(25.6 \%)$ and in state- 
owned/collective enterprises (7\%). Household heads in rich and poor categories are significantly more likely to be employed in collective and private enterprises (respectively $30.3 \%$ and $27.7 \%$ ) and are also more likely to be self-employed (with employees in the case of the rich group and without employees in the case of the poorest group). These results show that entrepreneurship is not specific to the middle class and, therefore, that the Chinese urban middle class cannot be limited to the 'old middle class'. The strong representation of the middle class in the salaried employee category and in the public sector confirms that there is a middle class of wage earners in China, the expansion of which has been promoted by the Chinese authorities (Chunling, 2010; Li, 2010).

Table 2: Characteristics (classification variables) of "poor", "middle-class" $\left[10,000\right.$ yuan ; $95^{\text {th }}$ percentile] and "rich" (urban households, 2009) ${ }^{1}$

\begin{tabular}{|c|c|c|c|c|}
\hline & $\begin{array}{c}\text { Poor } \\
N=573\end{array}$ & $\begin{array}{c}\text { Middle-class } \\
\qquad \mathrm{N}=681\end{array}$ & $\begin{array}{c}\text { Rich } \\
\mathrm{N}=66\end{array}$ & $\begin{array}{c}\text { All } \\
N=1320\end{array}$ \\
\hline \multicolumn{5}{|l|}{ Education } \\
\hline No school & $19.7 \%$ & $10.0 \%$ & $10.6 \%$ & $14.2 \%$ \\
\hline Primary school & $19.7 \%$ & $8.5 \%$ & $6.1 \%$ & $13.3 \%$ \\
\hline Secondary school & $48.0 \%$ & $45.4 \%$ & $37.9 \%$ & $46.1 \%$ \\
\hline Technical /Vocational degree & $7.5 \%$ & $17.9 \%$ & $21.2 \%$ & $13.6 \%$ \\
\hline Superior & $5.1 \%$ & $18.2 \%$ & $24.2 \%$ & $12.8 \%$ \\
\hline \multicolumn{5}{|l|}{ Occupation } \\
\hline Inactive / Seeking work & $36.3 \%$ & $6.5 \%$ & $1.5 \%$ & $19.2 \%$ \\
\hline Professional / Technical worker & $5.1 \%$ & $15.7 \%$ & $24.2 \%$ & $11.5 \%$ \\
\hline Administrator / Executive & $2.8 \%$ & $8.1 \%$ & $7.6 \%$ & $5.8 \%$ \\
\hline Office staff & $2.4 \%$ & $5.6 \%$ & $3.0 \%$ & $4.1 \%$ \\
\hline Skilled worker & $4.7 \%$ & $5.4 \%$ & $3.0 \%$ & $5.0 \%$ \\
\hline Non-skilled worker & $5.4 \%$ & $3.2 \%$ & $3.0 \%$ & $4.2 \%$ \\
\hline Service worker & $12.0 \%$ & $7.5 \%$ & $18.2 \%$ & $10.0 \%$ \\
\hline Other & $8.0 \%$ & $4.8 \%$ & $3.0 \%$ & $6.1 \%$ \\
\hline Retired & $23.2 \%$ & $43.2 \%$ & $36.4 \%$ & $34.2 \%$ \\
\hline \multicolumn{5}{|l|}{ Employment status } \\
\hline No job & $59.5 \%$ & $49.6 \%$ & $37.9 \%$ & $53.3 \%$ \\
\hline Self-employed with employees & $2.3 \%$ & $2.1 \%$ & $9.1 \%$ & $2.5 \%$ \\
\hline Self-employed with no employees & $12.4 \%$ & $6.5 \%$ & $9.1 \%$ & $9.2 \%$ \\
\hline Paid employee & $24.8 \%$ & $41.4 \%$ & $43.9 \%$ & $34.3 \%$ \\
\hline Other status & $1.0 \%$ & $0.4 \%$ & $0 \%$ & $0.7 \%$ \\
\hline \multicolumn{5}{|l|}{ Work unit } \\
\hline No job & $59.5 \%$ & $49.6 \%$ & $37.9 \%$ & $53.3 \%$ \\
\hline Government / State service & $8.9 \%$ & $25.6 \%$ & $25.8 \%$ & $18.3 \%$ \\
\hline State-owned enterprise & $3.8 \%$ & $7.0 \%$ & $6.1 \%$ & $5.6 \%$ \\
\hline Collective / Private / Individual enterprise & $27.7 \%$ & $17.8 \%$ & $30.3 \%$ & $22.7 \%$ \\
\hline
\end{tabular}

Source: CHNS (2009).

Notes: (1) Bold characters denote the fact that the value is significantly higher in the cluster than in the rest of the population (adjusted standardized residuals of $\mathrm{khi}^{2}$ for categorical variables, $\mathrm{p}<0.05$ and independent samples $t$-test for continuous variables, $p<0.10$ ); italic characters do the same for values significantly lower in the cluster than in the rest of the population. 
Table 3: Characteristics (characterization variables) of "poor", "middle-class" $\left[10,000\right.$ yuan ; $95^{\text {th }}$ percentile] and "rich" (urban households, 2009)

\begin{tabular}{|c|c|c|c|c|}
\hline & $\begin{array}{c}\text { Poor } \\
N=573\end{array}$ & $\begin{array}{c}\text { Middle-class } \\
\mathrm{N}=681 \\
\end{array}$ & $\begin{array}{l}\text { Rich } \\
N=66\end{array}$ & $\begin{array}{c}\text { All } \\
N=1320\end{array}$ \\
\hline \multicolumn{5}{|l|}{ Province } \\
\hline Liaoning & $7.2 \%$ & $11.7 \%$ & $12.1 \%$ & $9.8 \%$ \\
\hline Heilongjiang & $5.1 \%$ & $16.9 \%$ & $16.7 \%$ & $11.7 \%$ \\
\hline Jiangsu & $7.7 \%$ & $13.8 \%$ & $18.2 \%$ & $11.4 \%$ \\
\hline Shandong & $11.0 \%$ & $10.6 \%$ & $18.2 \%$ & $11.1 \%$ \\
\hline Henan & $12.4 \%$ & $10.7 \%$ & $6.1 \%$ & $11.2 \%$ \\
\hline Hubei & $12.4 \%$ & $9.5 \%$ & $6.1 \%$ & $10.6 \%$ \\
\hline Hunan & $14.1 \%$ & $10.3 \%$ & $9.1 \%$ & $11.9 \%$ \\
\hline Guangxi & $18.0 \%$ & $6.3 \%$ & $1.5 \%$ & $11.1 \%$ \\
\hline Guizhou & $12.2 \%$ & $10.1 \%$ & $12.1 \%$ & $11.1 \%$ \\
\hline \multicolumn{5}{|l|}{ Head's characteristics } \\
\hline Age (mean) & 57.5 & 57.6 & 57.7 & 57.6 \\
\hline Married & $77.5 \%$ & $84.4 \%$ & $90.9 \%$ & $81.7 \%$ \\
\hline Female & $27.9 \%$ & $22.5 \%$ & $10.6 \%$ & $24.2 \%$ \\
\hline Rural hukou & $12.7 \%$ & $4.9 \%$ & $9.2 \%$ & $8.4 \%$ \\
\hline \multicolumn{5}{|l|}{ Housing } \\
\hline Tenant & $16.5 \%$ & $8.7 \%$ & $7.7 \%$ & $12.1 \%$ \\
\hline Homeowner & $33.3 \%$ & $16.4 \%$ & $18.5 \%$ & $24.0 \%$ \\
\hline Homeowner (purchased) & $50.2 \%$ & $74.9 \%$ & $73.8 \%$ & $63.8 \%$ \\
\hline Surface per capita (mean) & 39.5 & 43.7 & 43.6 & 41.9 \\
\hline Rooms per capita (mean) & 1.5 & 1.8 & 1.9 & 1.7 \\
\hline \multicolumn{5}{|l|}{ Household size and activity } \\
\hline Household size (mean) & 3.2 & 2.6 & 2.5 & 2.9 \\
\hline Activity ratio (mean) & 0.28 & 0.40 & 0.47 & 0.35 \\
\hline \multicolumn{5}{|l|}{ Household income } \\
\hline Annual per capita income (mean) & 5,063 & 18,171 & 66,299 & 14,887 \\
\hline \multicolumn{5}{|l|}{ Household income structure } \\
\hline Business income & $11.1 \%$ & $7.9 \%$ & $13.6 \%$ & $9.5 \%$ \\
\hline Agricultural income & $3.9 \%$ & $0.9 \%$ & $0.1 \%$ & $2.1 \%$ \\
\hline Wage & $39.2 \%$ & $46.1 \%$ & $48.0 \%$ & $43.3 \%$ \\
\hline Retirement income & $23.1 \%$ & $39.3 \%$ & $31.0 \%$ & $32.0 \%$ \\
\hline Other income & $22.8 \%$ & $5.8 \%$ & $7.2 \%$ & $13.1 \%$ \\
\hline \multicolumn{5}{|c|}{ Household appliances and equipment } \\
\hline Own a computer & $28.1 \%$ & $47.1 \%$ & $59.1 \%$ & $39.4 \%$ \\
\hline Own a car & $4.0 \%$ & $6.9 \%$ & $15.1 \%$ & $6.1 \%$ \\
\hline Equipment goods index (mean) & 0.42 & 0.55 & 0.62 & 0.50 \\
\hline \multicolumn{5}{|l|}{ Urbanicity } \\
\hline Urbanization index (mean) & 83.9 & 88.1 & 88.4 & 86.4 \\
\hline
\end{tabular}

Source: CHNS (2009).

Notes: (1) Bold characters denote the fact that the value is significantly higher in the cluster than in the rest of the population (adjusted standardized residuals of $\mathrm{khi}^{2}$ for categorical variables, $\mathrm{p}<0.05$ and independent samples $\mathrm{t}$-test for continuous variables, $\mathrm{p}<0.10$ ); italic characters do the same for values significantly lower in the cluster than in the rest of the population. 
The description of the three income groups based on characterization variables (Table 3 ) calls for several additional comments. The provincial location of different income groups reflects the traditional pattern of the distribution of wealth between Chinese provinces. The richest category tends to be more concentrated in the coastal province of Shandong, while the poorest group is overrepresented in poorer inland provinces (Guangxi, Hunan, Hubei). Members of the middle class are significantly more likely to live in Jiangsu, the richest province in our dataset, and in the northeastern provinces of Heilongjiang and Liaoning. ${ }^{12}$ Furthermore, the Chinese urban middle class has specific characteristics in terms of housing. A higher percentage of its members are homeowners (75\%) and have significantly more spacious homes $\left(44 \mathrm{~m}^{2}\right.$ on average). This may be evidence of the role of housing in the rise of middle class values, as documented by Tomba $(2004,2010)$. In terms of household appliances and equipment, the middle class is in an intermediate position between the poor and the rich. For example, $47 \%$ of middle-class households own a computer, while $7 \%$ own a car. The household appliances and equipment index is also significantly higher in the middle class group than among poor households but significantly lower than for rich households. Finally, the urbanicity index for the middle class is close to the index for the rich category. This indicates that households belonging to the middle class are significantly more likely to live in highly urbanized areas characterized by high population density, significant economic activity and coexisting traditional and modern markets, but also a high level of sanitation, housing, education, health infrastructures, transport and communication infrastructures, etc.

\subsection{The heterogeneous composition of China's middle class}

To analyze the composition of the urban middle class, we apply a mixed classification approach to the four variables describing the educational and occupational profile of the households included in the sample (level of education, primary occupation, employment status and work unit) of households heads belonging to the middle income class. Mixed classification involves hierarchical cluster analysis and consolidates the appropriate partition through k-means iterations aimed at maximizing between-cluster variance while minimizing within-cluster variance. The appropriate partition, i.e. the appropriate number of clusters, is based on the analysis of the dendrogram and the analysis of two indicators that respectively (i) maximize the marginal improvement of the between to within-cluster variance ratio from one partition to another and (ii) minimize the effect of k-means clustering on that ratio. Based on these criteria, we adopt a four-group classification. Finally, we compare the distributions of each active (classification) variable to give a precise description of each cluster (Table 4). We also provide a detailed examination of clusters by comparing the distributions (or means) of a set of additional informative (characterization) variables (Table 5).

Table 4: Characteristics (classification variables) of clusters derived from mixed classification procedure (urban households, 2009) ${ }^{1}$

\begin{tabular}{lcccccc}
\hline Classification variables & $\mathbf{A}$ & $\mathbf{B}$ & $\mathbf{C}$ & $\mathbf{D}$ & All $\mathbf{M C}$ & All \\
$\mathbf{N}=\mathbf{3 3 8}$ & $\mathbf{N = 8 3}$ & $\mathbf{N = 7 9}$ & $\mathbf{N = 1 8 1}$ & $\mathbf{N = 6 8 1}$ & $\mathbf{N = 1 3 2 0}$ \\
\hline Education & & & & & & \\
\hline No school & $\mathbf{1 7 . 2 \%}$ & $10.8 \%$ & $0 \%$ & $0.6 \%$ & $10.0 \%$ & $14.2 \%$ \\
Primary school & $\mathbf{1 4 . 2 \%}$ & $7.2 \%$ & $3.8 \%$ & $0.6 \%$ & $8.5 \%$ & $13.3 \%$ \\
Secondary school & $42.6 \%$ & $\mathbf{6 9 . 9 \%}$ & $\mathbf{7 3 . 4 \%}$ & $27.1 \%$ & $45.4 \%$ & $46.1 \%$ \\
Technical /Vocational degree & $13.0 \%$ & $9.6 \%$ & $20.3 \%$ & $\mathbf{2 9 . 8 \%}$ & $17.9 \%$ & $13.6 \%$ \\
Superior & $13.0 \%$ & $2.4 \%$ & $2.5 \%$ & $\mathbf{4 2 . 0 \%}$ & $18.2 \%$ & $12.8 \%$ \\
\hline Occupation & & & & & & \\
\hline
\end{tabular}

\footnotetext{
${ }^{12}$ In 2011, Jiangsu had the second highest regional GDP after Guangdong. Jiangsu has benefited greatly from the open door policy since the late 1970s and has become one of the most important locations for exports and foreign direct investment. Heilongjiang and Liaoning are industrialized provinces and have benefited from a policy to revitalize the old industrial bases of Northeast China implemented in 2003.
} 


\begin{tabular}{|c|c|c|c|c|c|c|}
\hline Inactive / Seeking work & $13.0 \%$ & $0 \%$ & $0 \%$ & $0 \%$ & $6.5 \%$ & $19.2 \%$ \\
\hline Professional or technical worker & $0 \%$ & $8.4 \%$ & $11.4 \%$ & $50.3 \%$ & $15.7 \%$ & $11.5 \%$ \\
\hline Administrator / Executive & $0 \%$ & $4.8 \%$ & $8.3 \%$ & $24.3 \%$ & $8.1 \%$ & $5.8 \%$ \\
\hline Office staff & $0 \%$ & $1.2 \%$ & $2.5 \%$ & $19.3 \%$ & $5.6 \%$ & $4.1 \%$ \\
\hline Skilled worker & $0 \%$ & $2.4 \%$ & $44.3 \%$ & $0 \%$ & $5.4 \%$ & $5.0 \%$ \\
\hline Non-skilled worker & $0 \%$ & $1.2 \%$ & $26.6 \%$ & $0 \%$ & $3.2 \%$ & $4.2 \%$ \\
\hline Service worker & $0 \%$ & $51.8 \%$ & $5.1 \%$ & $2.2 \%$ & $7.5 \%$ & $10.0 \%$ \\
\hline Other & $0 \%$ & $30.1 \%$ & $1.3 \%$ & $3.9 \%$ & $4.8 \%$ & $6.1 \%$ \\
\hline Retired & $87.0 \%$ & $0 \%$ & $0 \%$ & $0 \%$ & $43.2 \%$ & $34.2 \%$ \\
\hline \multicolumn{7}{|l|}{ Employment status } \\
\hline No job & $100.0 \%$ & $0 \%$ & $0 \%$ & $0 \%$ & $49.6 \%$ & $53.3 \%$ \\
\hline Self-employed with employees & $0 \%$ & $16.9 \%$ & $0 \%$ & $0 \%$ & $2.1 \%$ & $2.5 \%$ \\
\hline Self-employed with no employees & $0 \%$ & $53.0 \%$ & $0 \%$ & $0 \%$ & $6.5 \%$ & $9.2 \%$ \\
\hline Paid employee & $0 \%$ & $26.5 \%$ & $100.0 \%$ & $100.0 \%$ & $41.4 \%$ & $34.3 \%$ \\
\hline Other status & $0 \%$ & $3.6 \%$ & $0 \%$ & $0 \%$ & $0.4 \%$ & $0.7 \%$ \\
\hline \multicolumn{7}{|l|}{ Work unit } \\
\hline No job & $100.0 \%$ & $0 \%$ & $0 \%$ & $0 \%$ & $49.6 \%$ & $53.3 \%$ \\
\hline Government / State service & $0 \%$ & $1.2 \%$ & $12.7 \%$ & $90.1 \%$ & $25.6 \%$ & $18.3 \%$ \\
\hline State-owned enterprise & $0 \%$ & $0 \%$ & $58.2 \%$ & $1.1 \%$ & $7.0 \%$ & $5.6 \%$ \\
\hline Collective / Private / Individual enterprise & $0 \%$ & $98.8 \%$ & $29.1 \%$ & $8.8 \%$ & $17.8 \%$ & $22.7 \%$ \\
\hline
\end{tabular}

Source: CHNS (2009).

Notes: (1) Bold characters denote the fact that the value is significantly higher in the cluster than in the rest of the middle class (adjusted standardized residuals of $\mathrm{khi}^{2}$ for categorical variables, $\mathrm{p}<0.05$ and independent samples t-test for continuous variables, $p<0.10$ ); italic characters do the same for values significantly lower in the cluster than in the rest of the middle class.

Table 5: Characteristics (characterization variables) of clusters derived from mixed classification procedure (urban households, 2009).

\begin{tabular}{|c|c|c|c|c|c|c|}
\hline Characterization variables & $\begin{array}{c}A \\
N=338\end{array}$ & $\begin{array}{c}\mathrm{B} \\
\mathrm{N}=83 \\
\end{array}$ & $\begin{array}{c}C \\
N=79\end{array}$ & $\begin{array}{c}D \\
N=181\end{array}$ & $\begin{array}{l}\text { All MC } \\
N=681\end{array}$ & $\begin{array}{c}\text { All } \\
N=1320\end{array}$ \\
\hline \multicolumn{7}{|l|}{ Province } \\
\hline Liaoning & $13.0 \%$ & $9.6 \%$ & $13.9 \%$ & $9.4 \%$ & $11.7 \%$ & $9.8 \%$ \\
\hline Heilongjiang & $13.3 \%$ & $2.4 \%$ & $21.5 \%$ & $28.2 \%$ & $16.9 \%$ & $11.7 \%$ \\
\hline Jiangsu & $15.7 \%$ & $20.5 \%$ & $11.4 \%$ & $8.3 \%$ & $13.8 \%$ & $11.4 \%$ \\
\hline Shandong & $12.1 \%$ & $8.4 \%$ & $8.9 \%$ & $9.4 \%$ & $10.6 \%$ & $11.1 \%$ \\
\hline Henan & $10.4 \%$ & $16.9 \%$ & $10.1 \%$ & $8.8 \%$ & $10.7 \%$ & $11.2 \%$ \\
\hline Hubei & $7.4 \%$ & $8.4 \%$ & $17.7 \%$ & $10.5 \%$ & $9.5 \%$ & $10.6 \%$ \\
\hline Hunan & $9.5 \%$ & $13.3 \%$ & $3.8 \%$ & $13.3 \%$ & $10.3 \%$ & $11.9 \%$ \\
\hline Guangxi & $7.4 \%$ & $13.3 \%$ & $6.3 \%$ & $1.1 \%$ & $6.3 \%$ & $11.1 \%$ \\
\hline Guizhou & $11.2 \%$ & $7.2 \%$ & $6.3 \%$ & $11.0 \%$ & $10.1 \%$ & $11.1 \%$ \\
\hline \multicolumn{7}{|l|}{ Head's characteristics } \\
\hline Age (mean) ${ }^{2}$ & 67.3 & 49.7 & 48.4 & 47.1 & 57.6 & 57.6 \\
\hline Married $^{2}$ & $77.2 \%$ & $94.0 \%$ & $94.9 \%$ & $89.0 \%$ & $84.4 \%$ & $81.7 \%$ \\
\hline Female $^{2}$ & $32.0 \%$ & $8.4 \%$ & $6.3 \%$ & $18.2 \%$ & $22.5 \%$ & $24.0 \%$ \\
\hline Rural hukou & $3.8 \%$ & $19.7 \%$ & $4.0 \%$ & $1.1 \%$ & $4.9 \%$ & $8.4 \%$ \\
\hline \multicolumn{7}{|l|}{ Housing } \\
\hline Tenant & $13.6 \%$ & $11.0 \%$ & $0 \%$ & $2.2 \%$ & $8.7 \%$ & $12.0 \%$ \\
\hline Homeowner & $13.6 \%$ & $43.9 \%$ & $20.5 \%$ & $7.2 \%$ & $16.4 \%$ & $23.8 \%$ \\
\hline Homeowner (purchased) & $72.8 \%$ & $45.1 \%$ & $79.5 \%$ & $90.6 \%$ & $74.9 \%$ & $64.2 \%$ \\
\hline
\end{tabular}




\begin{tabular}{|c|c|c|c|c|c|c|}
\hline Surface per capita (mean) & 46.7 & 51.5 & 34.8 & 38.6 & 43.7 & 41.9 \\
\hline Rooms per capita (mean) & 2.0 & 1.9 & 1.4 & 1.6 & 1.8 & 1.7 \\
\hline \multicolumn{7}{|l|}{ Household size and activity } \\
\hline Household size (mean) ${ }^{2}$ & 2.5 & 3.0 & 2.8 & 2.6 & 2.7 & 2.9 \\
\hline Activity ratio (mean) ${ }^{2}$ & 0.13 & 0.65 & 0.68 & 0.68 & 0.40 & 0.35 \\
\hline \multicolumn{7}{|l|}{ Household income } \\
\hline Annual per capita income (mean) & 18,571 & 16,818 & 16,266 & 18,874 & 18,171 & 14,887 \\
\hline \multicolumn{7}{|l|}{ Household income structure } \\
\hline Business income & $5.9 \%$ & $35.7 \%$ & $0.9 \%$ & $2.4 \%$ & $7.9 \%$ & $9.5 \%$ \\
\hline Agricultural income & $0.6 \%$ & $4.4 \%$ & $0.6 \%$ & $0 \%$ & $0.9 \%$ & $2.1 \%$ \\
\hline Wage & $16.8 \%$ & $42.4 \%$ & $82.6 \%$ & $86.8 \%$ & $46.1 \%$ & $43.3 \%$ \\
\hline Retirement income & $68.9 \%$ & $12.2 \%$ & $12.3 \%$ & $7.5 \%$ & $39.3 \%$ & $32.0 \%$ \\
\hline Other income & $7.8 \%$ & $5.3 \%$ & $3.7 \%$ & $3.2 \%$ & $5.8 \%$ & $13.1 \%$ \\
\hline $\begin{array}{lll}\text { Household appliances } & \text { and } \\
\text { equipment } & & \\
\end{array}$ & & & & & & \\
\hline Own a computer & $36.3 \%$ & $41.5 \%$ & $54.4 \%$ & $66.7 \%$ & $47.1 \%$ & $39.4 \%$ \\
\hline Own a car & $5.3 \%$ & $15.7 \%$ & $3.8 \%$ & $7.2 \%$ & $6.9 \%$ & $6.1 \%$ \\
\hline Equipment goods index (mean) & 0.51 & 0.52 & 0.57 & 0.62 & 0.55 & 0.50 \\
\hline \multicolumn{7}{|l|}{ Urbanicity } \\
\hline Urbanization index (mean) & 88.0 & 85.2 & 88.1 & 89.6 & 88.1 & 86.4 \\
\hline
\end{tabular}

Source: CHNS (2009).

Notes: (1) Bold characters denote the fact that the value is significantly higher in the cluster than in the rest of the population (adjusted standardized residuals of $\mathrm{khi}^{2}$ for categorical variables, $\mathrm{p}<0.05$ and independent samples $t$-test for continuous variables, $\mathrm{p}<0.10$ ); italic characters do the same for values significantly lower in the cluster than in the rest of the middle class. (2) For these variables, the significance of values is tested in clusters B, C and D by comparison with the rest of the middle class in these same clusters, in order to avoid the bias due to the strong proportion of elderly in group $A$.

\section{First group (A): Elderly and inactive middle class}

The first cluster includes households headed by someone with a low level of education and who is retired, inactive or unemployed. Elderly households represent $87 \%$ of the membership of this group. From our point of view, the identification of an elderly and inactive middle class in urban China is a new finding, particularly since the share of this group in the middle class as a whole is approximately $50 \%$. The chief focus of sociological research on the Chinese middle class is the working-age population. In other words, sociological studies do not consider the possibility of an elderly middle class. Conducting an investigation at a household level helps to broaden the scope of the analysis. Another interesting result is that, with a mean income significantly higher than the three other groups put together, elderly households are located at the top of the income distribution in the middle class. This result is difficult to interpret. The role of the urban pension system is a crucial factor in explaining the relatively favorable position of elderly people since almost $70 \%$ of the mean income of this group is composed of retirement income (Table 5). Despite the constraints related to population aging that threaten the financial stability of the pension system, there have been improvements in the provision of support to the elderly at two levels. First, the coverage of the urban pension system has improved as a result of various institutional reforms (Wang, 2006). ${ }^{13}$ Second, the Chinese authorities recently introduced a series of reforms aimed at increasing pensions.

\footnotetext{
${ }^{13}$ One of the most emblematic reforms is the 1997 reform, which established a three-pillar system for old-age pensions for enterprise employees (in line with World Bank recommendations). The system combines (i) a pay-as-you-go basic pension; (ii) a supplementary pension based on individual accounts and (iii) a voluntary pension scheme.
} 
For example, for eight consecutive years, the pension paid to enterprise retirees has increased significantly: in 2012, the average basic pension was 1,721 yuan, compared to 700 yuan in $2005 .{ }^{14}$

When looking at income structure (Table 5), the significant share of wages and other income (whose main component is private transfers from other households) indicates that elderly urban households also depend, at least partly, on their children and relatives, whether they belong to the same household or not. This form of financial support to the elderly is deeply ingrained in Chinese culture through the tradition of filial piety (Cheung and Kwan, 2009). However, the level of support seems relatively limited since wages and other income only account for $25 \%$ of the income of elderly households. The limited dependency of the elderly on family support is probably the result of the erosion of support from children, a trend related to modernization (Cheung and Kwan, 2009) and the decline of cohabitation with children or other relatives (Meng and Luo, 2008), but also the expansion of the pension system (Mu and Du, 2012).

Finally, the elderly and the inactive middle class seem largely insensitive to modernism and are unlikely to drive socio-economic change. The household appliances and equipment index and the computer and car ownership rates are significantly lower than in other middle class groups. Elderly households are also more likely to be tenants. We may argue that the values of the elderly and the inactive middle class are unrelated to modern, westernized consumption patterns.

\section{Second group (B): ‘Old' middle class}

The second cluster is mainly composed of households headed by self-employed workers, either with no employee $(53 \%)$ or with employees (17\%). However, it is important to note that the second group also includes wage earners since more than $25 \%$ of household heads are salaried employees. Another distinctive feature of this group is the fact that household heads are not involved in the public sector but are almost exclusively employed in collective and private enterprises. They are also more likely to work as service workers, whatever their employment status or work unit. The occupational profile of this group suggests a small business community often referred as the 'old' middle class in the literature on social stratification (Chunling, 2010). This class (not to be confused with the capitalist class composed of managers and owners of large exportoriented firms) is composed of moderately well-off households. First, as shown in Table 5, the mean per capita income is lower than the rest of the middle class. Second, approximately $20 \%$ of household heads in the old middle class are rural hukou holders. As noted by Lu (2002), a significant proportion of this small business community consists of rural-to-urban migrants, many of whom were originally peasants. Once they have migrated to cities, their rural hukou status means that they are often subject to wage and employment discrimination and have limited access to education, housing and social benefits (Liu, 2005). Because of barriers to entry into the formal urban sector, they often opt to open small informal businesses to improve their socio-economic status (Meng, 2001). ${ }^{15}$ It also should be noted that the old middle class is relatively small since it represents just $12 \%$ of the middle class as a whole (which includes a non-negligible proportion of wage earners, as noted above). Therefore, in the Chinese context, entrepreneurship is not the main determinant of middle class membership.

Characterization variables provide useful additional information. Households belonging to the small business class are more likely to own a car (over $15 \%$, compared to $7 \%$ for the middle class as a whole). One possible interpretation is that their entrepreneurial activity requires a high degree of mobility. Households belonging to this group also tend to live in urban areas with a low degree of

\footnotetext{
${ }^{14}$ http://www.cs.com.cn/english/finance/201301/t20130115 3820292.html.

15 Meng (2001) explains that migrants in the urban informal sector have two employment options: salaried employment or selfemployment. Meng shows that being employed as a wage earner is a default strategy, while self-employment is a deliberate choice.
} 
urbanicity and are overrepresented among long-standing homeowners. This suggests that the old middle class tends not to live in modern urban areas.

\section{Third group (C): Marginal middle class}

The third group identified in this study describes households whose heads are low-wage earners employed by enterprises (whether private, collective or state-owned) and skilled or unskilled workers. Their level of education is mostly intermediate (middle school and technical or vocational degree). This cluster corresponds to a working class whose members have benefited from economic reforms aimed at promoting industrialization (many of them have secured a permanent contract in the expanding manufacturing sector). Job stability partly explains why they have reached a standard of living high enough to ensure a certain level of socio-economic security and to avoid poverty. However, on average, households in this group have a significantly lower annual per capita income than other middle class groups. The existence of a lower component among the Chinese urban middle class is an interesting result consistent with the findings of Chunling (2010). Using the same terminology as Chunling (2010), this lower category may be defined as the marginal middle class. However, the share of the lower middle class in the middle class as a whole is relatively limited (no more than $12 \%)$. In terms of characterization variables, it is impossible to establish a profile in terms of place of residence (province, urbanicity) or equipment (household appliances). However, as we might have anticipated, households in the lower middle class tend to live in significantly smaller dwellings than other groups.

\section{Fourth group (D): 'New' middle class}

The last group comprises households whose heads are well-educated higher-wage earners (mainly professional and technical workers, administrators, executives and office workers). Members of this group are almost exclusively employed in the public sector as state employees (over $90 \%$ ). This suggests that the Chinese authorities have played a crucial role in promoting the expansion of the middle class. Tomba (2004) argues that the development of a category of salaried professionals in the public sector "has been as much the outcome of the social engineering project of the contemporary reformist state and its agencies as it has been a consequence of the opening up of the economy and society" (Tomba, 2004: 3). To support this idea, Tomba (2004) explains that, in the mid1990s, the Chinese state significantly increased the wages of employees working in government departments and state services, particularly in sectors such as health care, education and science and academia. Based on Chunling (2010), the fourth component may be described as the 'new' middle class. It is the richest component of the Chinese urban middle class, with a mean annual per capita household income of around 19,000 yuan, which is significantly higher than other middle class groups (particularly the old and lower middle class groups). The new middle class accounts for approximately $26 \%$ of the middle class as a whole and is likely the most visible component in terms of consumption behaviours.

From our point of view, the characterization variables show that the new middle class is attracted to modern lifestyles. Three arguments support this view. First, households belonging to this group have the highest household appliances and equipment index and the highest computer ownership rate (approximately $67 \%$ compared to $47 \%$ for the middle class as a whole), suggesting that they have a significant interest in high-technology and high-quality products. Second, households belonging to the new middle class tend to have purchased their dwelling recently and to live in high-urbanicity areas. ${ }^{16}$ This indicates that they have a strong preference for modern housing in areas offering high-quality services (transportation, communication, education, health care, etc.)

\footnotetext{
${ }^{16}$ Table 5 also shows that members of the new middle class tend to live in smaller dwellings than other middle-class groups, perhaps because they tend to be recent homeowners and have been constrained by the growth of the real estate market.
} 
and confirms the role of housing and place of residence as social markers in urban China (Li and Niu, 2003; Tomba, 2004, 2010). Tomba (2004) provides evidence of the construction of "new cities" designed as residential compounds for the professional middle class. Tomba (2004) also emphasizes the active role of the Chinese authorities in promoting residential segregation through its involvement in housing distribution and through the provision of homeownership subsidies, mainly for public sector employees. Three, although the proportion of married household heads is not statistically different between the old middle class, the marginal middle class and the new middle class, the share of female-headed households is significantly greater in the new middle class. This may be evidence of the increasing access of women to high-paying jobs in the public sector, but also of their increasing role in urban Chinese families with a high socio-economic status. In line with modernization, their increasing role could be interpreted as a specific dimension of a more general transformation of traditional family values that also includes the transformation of intergenerational relations and the decline of filial piety (Whyte, 2005).

\section{Conclusion}

This paper does not claim to provide an accurate estimate of the size of the Chinese urban middle class since CHNS data are not nationally representative and do not include a number of major cities, but also because the identification of the middle class implies making difficult and debatable methodological choices. The study had two main objectives: (i) to analyze the structure of the Chinese urban middle class and to demonstrate its heterogeneity; (ii) to propose an innovative statistical approach combining an economic definition and a sociological definition of the middle class.

First, we defined an income criterion to delimit the boundaries of the Chinese middle class. After comparing several income criteria, we chose to define the middle income class as households with an annual per capita income of between 10,000 yuan and the $95^{\text {th }}$ percentile of the income distribution. We showed that the growth of the middle class is a recent phenomenon that began in the early 2000s. For 2009, we estimated the size of the urban middle class in the nine provinces covered by CHNS data at nearly $50 \%$ of the total population. We also showed that the urban middle class has specific occupational and educational characteristics compared to the poorest group and the rich.

Second, we used a classification procedure using information on occupation and education to examine the composition of the middle income class. The cluster analysis showed the significant heterogeneity of the urban middle class by identifying four distinct clusters: (i) the elderly and the inactive middle class, mainly composed of pensioners; (ii) the old middle class, composed of selfemployed workers; (iii) the marginal middle class, composed of skilled and unskilled workers; and (iv) the new middle class, composed of highly educated and highly-paid employees in the public sector. The core of the Chinese urban middle class was found to be composed of elderly households and high-earning households accounting for approximately $80 \%$ of the urban middle class as a whole.

It is important to emphasize that the four groups have distinctive features when it comes to housing, household appliances and equipment and province of residence. More specifically, our results suggest that the four components of the middle class have different consumption patterns. The Chinese middle class is often seen as driving the consumer revolution by adopting modern, westernized consumption patterns. Our study shows that these behaviors are mainly characteristic of the new middle class. The new middle class is clearly rooted in modernity, with relatively high computer ownership rates and a taste for modern housing. This result has two implications. First, of the four components of the Chinese urban middle class, the new middle class appears to be the main driver of socio-economic change through consumption. The role of the upper middle class in the diffusion of new consumption patterns is probably explained by its greater exposure to globalization 
and westernization, but also by the active role of the Chinese state in promoting high-wage earners in the public sector (Tomba, 2004). However, it is important to keep in mind that the new middle class accounts for less than $14 \%$ of urban households in our sample. Second, consistent with Elfick (2011) and Tomba (2004), we suggest that the development of new consumption patterns is indicative of the emergence of common values among the upper-middle class, a key factor in the formation of class identity. 


\section{References}

ADB, 2010, "The rise of Asia's middle class", Special chapter in ADB (Ed.), Key indicators for Asia and the Pacific 2010, Asian Development Bank: Metro Manila (Philippines).

Alesina, A., Perotti, R. 1996, "Income distribution, political instability and investment", European Economic Review, 40(6): 1203-1228.

Banerjee, A., Duflo, E. 2008, "What is middle class about the middle classes around the world?", Journal of Economic Perspectives, 22(2): 3-28.

Birdsall, N. 2010, "The (indispensable) middle class in developing countries", in R. Kanbur, M. Spence (Eds.), Equity and growth in a globalizing world, World Bank (Commission on Growth and Development): Washington DC.

Birdsall, N., Graham, C., Pettinato, S. 2000, "Stuck in tunnel: Is globalization muddling the middle?", Brookings Institution Working Paper, $\mathrm{n}^{\circ} 14$.

Blackburn, M., Bloom, D. 1985, "What is happening to the middle class?", American Demographics, 7(1): 18-25.

Bonnefond, C., Clément, M. 2012, "An analysis of income polarization in rural and urban China", Post-Communist Economies, 24(1): 15-37.

Burkhauser, R.V., Crews, A.D., Daly, M.C., Jenkins, S.P. 1996, Income mobility and the middle class, AEI Press: Washington DC.

Castellani, F., Parent, G. 2011, "Being 'middle class' in Latin America”, OECD Development Centre Working Paper, $\mathrm{n}^{\circ} 305$.

Chen, A. 2002, "Capitalist development, entrepreneurial class and democratization in China", Political Science Quarterly, 117(3): 401-422.

Cheung, C.K., Kwan, A.Y.H. 2009, "The erosion of filial piety by modernisation in Chinese cities", Ageing \& Society, 29: 179-198.

Chunling, L. 2003, "Zhongguo dangdai zhongchan jieceng de goucheng ji bili" (The composition and size of China's contemporary middle class), Zhongguo renkou kexue (Chinese Population Science), 6: 25-32.

Chunling, L. 2010, “Characterizing China's middle class: Heterogeneous composition and multiple identities", in C. Li (Ed.), China's emerging middle class. Beyond economic transformation, Brooking Institution Press: Washington DC.

Coleman, R.P. 1983, "The continuing significance of social class to marketing", Journal of Consumer Research, 10: 265-280.

Deutsche Bank Research, 2009, “Emerging Asia's middle class. A force to be reckoned with, Asia Current Issues", Deutsche Bank: Frankfurt am Main.

Easterly, W. 2001, "The middle class consensus and economic development", Journal of Economic Growth, 6(4): 317-335. 
Elfick, J. 2011, "Class formation and consumption among middle-class professionals in Shenzhen", Journal of Current Chinese Affairs, 40(1): 187-201.

Filmer, D., Pritchett, L.H. 2001, "Estimating wealth effects without expenditure data-or tears: An application to education enrolments in States of India", Demography, 38(1): 115-132.

Foellmi, R., Zweimuller, J. 2006, "Income distribution and demand-induced innovations", Review of Economic Studies, 73(4): 941-960.

Hanlong, L. 2010, "The Chinese middle class and Xiaokang society", in C. Li (Ed.), China's emerging middle class. Beyond economic transformation, Brooking Institution Press: Washington DC.

Hollingshead, A.B., Redlich, F.C. 1958, Social class and mental illness, Wiley: New York.

Hollingshead, A.B. 1976, Four factor index of social status, Yale University Press: New Haven.

Horrigan, M.W., Haugen, S.E. 1988, "The declining middle class thesis: A sensitivity analysis", Monthly Labor Review, 111(5): 3-13.

Jing, Y. 2010, "Stumbling on the rocky road: Understanding China's middle class", International Journal of China Studies, 1(2) : 435-458.

Jones-Smith, J.C., Popkin, B.M. 2010, "Understanding community context and adult health changes in China: Development of an urbanicity scale", Social Science \& Medicine, 71(8): 1436-1446.

Kharas, H. 2010, "The emerging middle class in developing countries", OECD Development Center Working Paper, $n^{\circ} 285$.

Landes, D. 1998, The wealth and poverty of Nations, Norton: New York.

Li, C. 2010, "Introduction: The rise of the middle class in the Middle Kingdom", in C. Li (Ed.), China's emerging middle class. Beyond economic transformation, Brooking Institution Press: Washington DC.

Li, J., Niu, X. 2003, "The new middle class in Peking: A case study", China Perspectives, 45(JanuaryFebruary).

Lipset, S.M. 1959, "Some social requisites of democracy: Economic development and political legitimacy", American Political Science Review, 53(1): 69-105.

Liu, Z. 2005, "Institution and inequality: The hukou system in China", Journal of Comparative Economics, 33(1): 133-157.

Loayza, N., Rigolini, J., Llorente, G. 2012, “Do middle classes bring institutional reforms?", Economics Letters, 116(3): 440-444.

Lu, X. 2002, Dangdai zhongguo shehuijieceng yanjiu baogao (Research report on social strata in contemporary China), Shehui kexue wenxian chubanshe: Beijing.

Lu, X. 2012, Social structure of contemporary China, World Scientific Publishing Company: Singapore.

Matsuyama, K. 2002, "The rise of mass consumption societies", Journal of Political Economy, 110(5): 1035-1070. 
McKinsey Global Institute, 2006, From 'made in China' to 'sold in China': The rise of the Chinese urban consumer, McKinsey\&Company.

Meng, X. 2001, "The informal sector and rural-urban migration. A Chinese case study", Asian Economic Journal, 15(1): 71-89.

Meng, X., Luo, C. 2008, "What determines living arrangements of the elderly in urban China", in B.A. Gustafsson, S. Li and T. Sicular (Eds.), Inequality and public policy in China, Cambridge University Press: Cambridge.

Milanovic, B., Yitzhaki, S., 2002, "Decomposing the world income distribution: Does the world have a middle class?", Review of Income and Wealth, 48(2): 155-178.

Mills, C.W. 1951, White collar: The American middle classes, Oxford University Press: New York.

$\mathrm{Mu}, \mathrm{R}$., Du, Y. 2012, “Pension coverage for parents and educational investment in children: Evidence from urban China", IZA Discussion Paper, n 6797.

Muller, E.N. 1997, "Economic determinants of democracy", in M.I. Midlarsky (Ed.), Inequality, democracy and economic development, Cambridge University Press: Cambridge University Press.

Murphy, K.M., Shleifer, A., Vishny, R. 1989, "Income distribution, market size and industrialization", The Quarterly Journal of Economics, 104(3): 537-564.

Peichl, A., Schaefer, T., Scheicher, C. 2010, "Measuring richness and poverty: A micro data application to Europe and Germany", Review of Income and Wealth, 56(3): 597-619.

Popkin, B.M., Du, S., Zhai, F., Zhang, B. 2009, "Cohort profile: The China health and nutrition survey. Monitoring and understanding socio-economic and health change in China, 1989-2011", International Journal of Epidemiology, 39: 1435-1440.

Pressman, S. 2007, "The decline of the middle class: An international perspective", Journal of Economic Issues, 41(1): 181-200.

Ravallion, M. 2010, "The developing world's bulging (but vulnerable) middle class", World Development, 38(4): 445-454.

Ravallion, M., Chen, S. 2007, "China's (uneven) progress against poverty", Journal of Development Economics, 82(1): 1-42.

Sosa Escudero, W., Petralia, S. 2010, "I can hear the grass grow: The anatomy of distributive changes in Argentina", CEDLAS Working Paper, $\mathrm{n}^{\circ} 0106$.

Thurow, L. 1987, "A surge in inequality", Scientific American, 256: 30-37.

Tomba, L. 2004, "Creating an urban middle class: Social engineering in Beijing", The China Journal, 51: $1-26$.

Tomba, L. 2010, "The housing effect: The making of China's social distinctions", in C. Li (Ed.), China's emerging middle class. Beyond economic transformation, Brooking Institution Press: Washington DC. 
Wang, D. 2006, "China's urban and rural old age security system: Challenges and options", China \& World Economy, 14(1): 102-116.

Wang, J., Davis, D. 2010, “China's new upper middle classes: The importance of occupational disaggregation", in C. Li (Ed.), China's emerging middle class. Beyond economic transformation, Brooking Institution Press: Washington DC.

Warner, W. L., Meeker, M., Eels, K. 1949, Social class in America: A manual of procedure for the measurement of social status, Science Research Associates: Chicago.

Whyte, M.K. 2005, "Continuity and change in urban Chinese family life", The China Journal, 53: 9-33.

Wilson, D., Dragusanu, R. 2008, "The expanding middle: The exploding world middle class and falling global inequality", Goldman Sachs, Global Economics Paper, $\mathrm{n}^{\circ} 170$.

Xiaohong, Z., Chen, Q. 2010, "Globalization, social transformation and the construction of China's middle class", in C. Li (Ed.), China's emerging middle class. Beyond economic transformation, Brooking Institution Press: Washington DC.

Yuan, Z., Wan, G., Khor, N. 2011, "The rise of the middle class in the People's Republic of China", ADB Economics Working Paper, $n^{\circ} 247$. 


\title{
Cahiers du GREThA Working papers of GREThA
}

\author{
GREThA UMR CNRS 5113 \\ Université Montesquieu Bordeaux IV \\ Avenue Léon Duguit \\ 33608 PESSAC - FRANCE \\ Tel : +33 (0)5.56.84.25.75 \\ Fax : +33(0)5.56.84.86.47 \\ http://gretha.u-bordeaux4.fr/
}

\begin{abstract}
Cahiers du GREThA (derniers numéros - last issues)
2013-08 : OUEDRAOGO Boukary, Acceptation et usages éducatifs des Technologies de I'Information et de la Communication (TIC) par les professeurs de l'Université de Ouagadougou (Burkina Faso) : une application du modèle TUAUT
\end{abstract}

2013-09: FRIGANT Vincent, Une comparaison de l'internationalisation des chaînes d'approvisionnement automobiles allemande et française

2013-10 : MOYES Patrick, Rearrangements and Sequential Rank Order Dominance

2013-11 : BECUWE Stéphane, BLANCHETON Bertrand, La place du vin dans les échanges internationaux de la France pendant la première mondialisation

2013-12 : LAVIGNE Stéphanie, NICET-CHENAF Dalila, DUPUY Claude, Where do "impatient" mutual funds invest? A special attraction for large proximate markets and companies with strategic investors

2013-13 : CARAYOL Nicolas, STERZI Valerio, Signaling and the Ownership of Academic Patents

2013-14 : PASTUREAU Guillaume, De l'usage social aux pratiques marchandes de l'argent. Une brève histoire des origines du microcrédit social

2013-15 : CHARLES Léo, Why did Switzerland succeed? An analysis of Swiss specializations (18851905)

2013-16 : PASTUREAU Guillaume, Du Mont-de-Piété à la Grameen Bank: la finance sociale à travers le temps et l'espace. Essai sur une cohérence institutionnelle et une diversité des pratiques

2013-17 : BECUWE Stéphane, BLANCHETON Bertrand, CHARLES Léo, First globalization: why did France miss the boat?

2013-18 : HARDY P.H., BENE C., DOYEN L., PEREAU J. C., MILLS D., Viability and resilience of smallscale fisheries through cooperative arrangements

2013-19 : BONNEFOND Céline, CLEMENT Matthieu, COMBARNOUS François, In search of the elusive Chinese urban middle class: An exploratory analysis

La coordination scientifique des Cahiers du GREThA est assurée par Sylvie FERRARI et Vincent FRIGANT. La mise en page est assurée par Anne-Laure MERLETTE. 